\title{
Öğrencilerin Besin Tüketim Alışkanlıkları Üzerine Bir Araştırma ${ }^{1}$
}

\author{
Merve IŞKIN \\ Sakarya Üniversitesi, Turizm Fakültesi. \\ e-posta: merveiskin25@gmail.com \\ Prof. Dr. Mehmet SARIIŞIK \\ Sakarya Üniversitesi, Turizm Fakültesi. \\ e-posta: msariisik@sakarya.edu.tr
}

\section{Öz}

Üniversite öğrencilerinin yaşadıkları dinamik çevre, aile ortamında uzak olmaları, düzensiz bir yaşam ve beslenme şartları nedeniyle tükettikleri besinler değişiklik gösterebilmektedir. Öğrencilerin tükettikleri besinlerin tespit edilmesi gelecekte ortaya çıabilecek beslenme bozuklukları ve diğer sorunlara karşı önlem alınması açısından önemlidir. $\mathrm{Bu}$ çalışmada üniversite öğrencilerinin besin tüketim alışkanlıkların belirlenmesi amaçlanmaktadır. Araştırmada nicel araştırma yöntemleri, veri toplama aracı olarak anketten faydalanılmış ve elde edilen veriler analize tabi tutulmuştur. Bulgulara göre: öğrencilerin peynir, tavuk eti, yumurta, pişmiş sebze, ekmek, çikolata-şeker, kuruyemiş, zeytin, simit, pilav-makarna, taze meyve ve tost-pizza gibi yiyecekleri çok sık tükettikleri saptanmıştır. Bunla beraber sakatat, balıketi, sucuk-sosis margarin ve pekmez gibi ürünler en az tüketilen yiyecekler olarak dikkat çekmektedir. Ayran ve çay çok tüketilen, alkol grupları ve süt ise en az tüketilen içeceklerdir.

Anahtar Kelimeler: Besin, Tüketim, Yiyecek-İçecek, Üniversite Öğrencileri

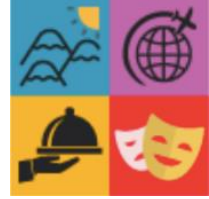

Türk Turizm Araştırmaları Dergisi Cilt. 1, Say1.1, 2017 ss.33-42.

DOI: $10.26677 /$ tutad.2017.2

\section{Önerilen Atıf:}

Işkın, M. ve Sarışık, M., (2017). Öğrencilerin Besin Tüketim Alışkanlıkları Üzerine Bir Araştırma, Türk Turizm Araştırmaları Dergisi, Cilt.1, Sayı.1, ss. 33-42.

\footnotetext{
${ }^{1} \mathrm{Bu}$ çalışma Sakarya Üniversitesi Sosyal Bilimler Enstitüsünde sunulan ve kabul edilen "Üniversite Öğrencilerinin Beslenme Alışkanlıkları Üzerine Bir Araştırma: Sakarya Üniversitesi Örneği” isimli tez çalışmasından geliştirilmiştir.
} 


\title{
A Research About Students' Nutrition Habits
}

\author{
Merve IŞKIN \\ Sakarya University, Faculty of Tourism. \\ e-posta: merveiskin25@gmail.com \\ Prof. Dr. Mehmet SARIIŞIK \\ Sakarya University, Faculty of Tourism. \\ e-posta: msariisik@sakarya.edu.tr
}

\begin{abstract}
Nutrients can be changed among university students because of living in dynamic environment is distant from their family, and the nutrients consumed due to irregular life and nutrition conditions. Identification of the foods consumed by the students is important in order to prevent future nutritional disorders and other problems. In this study, it is aimed to determine food consumption habits of university students. Quantitative research methods were used in the research, the questionnaire was used as a data collection tool and the obtained data was analyzed. According to findings: it was determined that students consumed foods such as cheese, chicken meat, eggs, cooked vegetables, bread, chocolate-sugar, nuts, olives, bagels, rice-pasta, fresh fruit and toast-pizza very frequently. In addition, products such as offal, fish, sausage, sausage margarine and molasses are the least consumed foods. Buttermilk and tea are highly consumed while alcohol groups and milk are the least consumed drinks.
\end{abstract}

Keywords: Food, Consumption, Food and Beverage, University Students

\section{Suggested Ctitation:}

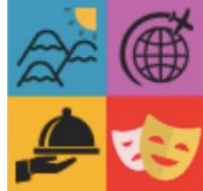

Journal of Turkish Tourism

Research

Vol. 1, Issue.1, 2017

pp. 33-42.

Işkın, M. and Sarıı̧ık, M., (2017). A Research About Students' Nutrition Habits, Journal of Turkish Tourism Research, Vol.1, Issue.1, pp. 33-42. 


\section{Gíriş}

Beslenme, insanlık tarihi kadar eski bir kavramdır. Çünkü beslenme insanın varlığı ile beraber ortaya çıkan en temel gereksinimlerden birisidir. İnsanların beslenme gereksinimlerini ilk olarak giderdikleri yöntem daha çok avcılık ve toplayıcılığa dayanmaktaydı. Daha çok insanlığın ilkel dönemlerine denk gelen bu beslenme şekli, dönemin sosyo-kültürel yaşayışını yansıtan en güzel örneklerden birisidir. Bu nedenle, bu dönemde tüketilen ürünler daha çok avlanan hayvanlar ve doğadan toplanan bitkilere dayanmaktadır.

Beslenme, kavramının anlam kazanması veya tartışılmasının temeli besin kavramdır. Besin kavramı beslenme kavramının işlevsellik kazanmasının da ön koşuludur. Çünkü bu insanın beslenmesi, yeterli ve dengeli beslenip beslenmemesi veya sağlıklı ve düzgün bir beslenme alışkanlığına sahip olup olmasının varacağı ilk nokta tüketilen besinlerdir. Eğer vücuda istenilen besinler, istenilen zamanda ve istenilen miktarda tüketilirse beslenme ile ilgili birçok problem ortadan kalkabilmektedir. Bu bilgiler 1şığında yeterli ve dengeli beslenme sağlıklı beslenme ile ilişkilidir. Sağlıklı beslenmenin temel koşulu ise besin (g1da) seçimidir (Alaunyte vd., 2015:12).

Beslenme ve besin konusunda birçok birey veya grup yaptıkları tercihler nedeniyle problemler yaşamaktadır. Bu iki kavram ile ilgili düzensiz ve değişken bir kültüre sahip kitlelerden biri de üniversite öğrencileridir. Genellikle ailelerinden uzakta bir ortama gitmek zorunda kalan üniversite öğrencilerinin değişen en temel alışkanlıklarından biri beslenme, tüketimleri de besindir. Beslenme gereksinimlerini gidermek zorunda kalan öğrenciler, bunu ya kendileri yapmak zorunda kalmakta ya da dışarıdan temin etmektedirler. Bu nedenle öğrencilerin genelde düzensiz besin tüketimine sahip oldukları söylenebilir.

Araştırmanın takip eden bölümünde besin kavramı ile ilgili literatür taramasına yer verilmiştir. Bu bölümde, besin kavramı, besin öğeleri, besin grupları ve öğrencilerin besin tüketimlerine ilişkin bilgiler yer almaktadır. Sonraki bölümde, araştırmanın amacı, önemi, ölçeği, evren ve örneklemi, veri toplama sürecine ilişkin bilgilerin yer aldığı araştırma metodolojisine yer verilmektedir. Takip eden bölümde, araştırma verilerine ilişkin bulgu ve yorumların bulunduğu bulgular bölümüne yer verilmiştir araştırma sonuç ve öneriler ile tamamlanmıştır.

\section{LITERATÜR ARAŞTIRMASI}

Yaşam sürdürmek için içeriğinde su, organik ve inorganik ögeler barındıran, yenilebilen ya da içilebilen, hayvan ve bitki dokuları "besin" olarak adlandırılır (Bulduk, 2002:22). Beslenme belli bir noktaya kadar karın doyurmak için veya fizyolojik güdüleri gidermek için kullanılmaktadır. Yeryüzünde bulunan besin çeşitliliği beslenmeyi insanlar için daha anlamlı hale getirmektedir. Doğada bulunan besin bileşimlerinin içinde değişik miktarlarda besin öğeleri bulunmaktadır. Besinlerde bulunan bu kimyasal moleküller tüketimden sonra sindirilerek parçalanmaktadır (Baban, 2010:3). Burada önemli olan yenilen veya içilen hayvan veya bitki dokularının hangisinin besin olarak tüketildiğidir. Bunun belirlenmesi de büyük oranda insan fizyolojisi veya vücudunun gereksinim duyduğu çeşit veya miktardır. Besinler besin ögeleri ve besin grupları olarak iki açıdan ele alınmaktadır. Bunlar aşağıda Tablo 1 de verilmektedir; 
Tablo 1: Besin Ögeleri ve Besin Grupları

\begin{tabular}{|c|c|c|c|}
\hline \multicolumn{3}{|c|}{ BESİN ÖGELERİ } & BESIN GRUPLARI \\
\hline $\begin{array}{l}\text { Enerji Veren Besin } \\
\text { Ögeleri }\end{array}$ & \multicolumn{2}{|c|}{ Enerji Vermeyen Besin Ögeleri } & \\
\hline \multirow[b]{3}{*}{$\begin{array}{l}\text { Karbonhidratlar } \\
\text { Yağlar } \\
\text { Vitaminler }\end{array}$} & \multicolumn{2}{|r|}{ Mineraller } & \\
\hline & \multicolumn{2}{|r|}{ Vitaminler } & \\
\hline & $\begin{array}{l}\text { Yağda eriyen } \\
\text { vitaminler } \\
\text { - A vitamini } \\
\text { - D vitamini } \\
\text { - E vitamini } \\
\text { - K vitamini }\end{array}$ & $\begin{array}{l}\text { Suda eriyen vitaminler } \\
\text { - Tiamin (B1), } \\
\text { - Riboflavin (B2), } \\
\text { - Niasin, } \\
\text { - Folik asit, } \\
\text { - B6, } \\
\text { - B12, } \\
\text { - Biotin, } \\
\text { - Pantetoik asit, } \\
\text { - Kolin, } \\
\text { - C }\end{array}$ & $\begin{array}{l}\text { Süt ve Süt Ürünleri } \\
\text { Et- Yumurta-Kurubaklagil } \\
\text { Grubu } \\
\text { Sebze-Meyve Grubu } \\
\text { Tahıl Grubu } \\
\text { Tuz- Şeker Tüketimi }\end{array}$ \\
\hline
\end{tabular}

Kaynak: (Baysal, 1990:11; Köksal, 2000:345; Bulduk, 2002:164; Türkan, 2005:25-31; Wetherilt, 2006: 9; Schwenk ve Schwenk, 2006:69; Tayar vd., 2011:327)’den uyarlanmıştır.

Besinler insanların beslenme ihtiyaçlarının gidermek için kullanılır. Bu besinler tüketim süreci içerisinde bir alışkanlığa dönüşmektedir. Bu da dünyada hızla yayılan kötü beslenme (malnutrition) kaynaklı sağlık problemleri nedeniyle, beslenme ile ilgili düzenlemeler, yeni planlamalar ve bunların uygulanması zorunlu kılmıştır. Örneğin; çocukluktan erişkinliğe geçiş döneminde evden uzakta daha fazla zaman geçiren gençler sağlıksız beslenme koşullarıyla karşılaşmaktadırlar. Bunları engellemek adına özellikle okullarda sağlıklı beslenme programlarının düzenlenmesinin bu sorunun çözümünde önemli bir rol oynayacağ 1 düşünülmektedir. Bu sağlıksız beslenme durumlarının başında öğün atlama gelmektedir. Fakat insan vücudunun fizyolojik dengesinin sağlanmasının yolu öğün örüntüsüne dikkat etmekten geçmektedir. Çünkü sağlıklı beslenmenin birincil şartı öğün atlamamaktır (Sormaz ve Şanlıer, 2015:1621). Ayrıca sağlam bir beslenme alışkanlığının oturtulması bazı önemli sağlık sorunları ile mücadelede de insanlara yardımcı olabilmektedir. Prostat hastalığı bu hastalıkların başında gelmektedir (Koniuszy vd., 2013:320).

Üniversite öğrencileri beslenme alışkanlıkları açsından ele alınabilecek en önemli gruplardan bir tanesidir. Gençlerin beslenme durumlarının zaten önemli olduğu bir ortamda, kendilerine has özellikleri genç grup içerisinde beslenme konusunda özellikle değerlendirilmeleri gerekmektedir. Ailelerinden kopmaları, farklı bir sosyal çevreye katılmaları, gündelik faaliyetlerinin değişimi gibi bir takım temel özellikler bazı önemli konularda olduğu gibi beslenmeleri üzerinde de oldukça etkili olabilmektedir.

Üniversite öğrencilerinin de içinde bulunduğu gençlerin beslenme alışkanlıklarının şekillenmesini sağlayan bazı faktörler aşağıda verilmektedir (Şanlıer vd., 2009:337).

- Birincil faktörler; kişisel yeme seçimleri, ailenin yeme biçimi, anne ve babanın yeme seçimi konusunda model olması, medya ve toplumsal normlar,

- Kişisel faktörler; davranışlar, inançlar, bilgiler, özsaygı, öğün ve atıştırmalık örüntüsü, ağırlık kontrolü ve

- Sosyal faktörler; aile, arkadaşlar ve diğer yakın çevredir. 
Üniversite öğrencileri çocukluk çağından erişkin döneme geçen ilk gruplardan biridir. Öğrenciler üniversite eğitimine başlamaları ile birlikte, ailelerinden ayrılarak dış etkilere açık bir hale gelmektedirler. Böylece kendi başlarına karar almalarını gerektirecek bir süreç başlamaktadır. Kendi başlarına almaları gerekecek temel kararların başında da beslenme ile ilgili kararlar gelmektedir. Bu yeni düzene ayak uydurma çabalarını şekillendiren unsurda ekonomik güçtür. Ekonomik gücü iyi olan öğrenciler beslenmelerini daha iyi bir şekilde şekillendirebilirler. Bu dönemin beslenme alışkanlığını önemli hale getiren bir diğer unsur eğitim sonrası yaşamı da etkileyebilmesidir. Üniversite eğitimi sonrası insanın kişiliği belli ölçülerde oturduğu için sahip olunan alışkanlıklar devam ettirilmeye çalışılır. Bu nedenle bu dönemde iyi beslenmeye özen gösterilmelidir (Mazıcıŏglu ve Öztürk, 2003:173).

Yetersiz ve dengesiz beslenmenin önemli bir toplumsal sorun olduğu Türkiye'de, bu sorunun yaşandığı en riskli gruplardan biride üniversite öğrencileridir. Ülkemizde üniversite öğrencileri düzenli bir beslenme alışkanlığına sahip değildir. Hatta bu kitle yetersiz ve dengesiz beslenmektedir. Türkiye'deki üniversite öğrencilerinin beslenme alışkanlığının olmaması temelde iki nedene bağlanmaktadır. Bunlar bilgisizlik ve ekonomik yetersizliktir. Üniversite öğrencilerinin ilk dönemlerinin adölesan dönemleri ile denk gelmesi bu süreci daha da zorlamaktadır. Dolayısı ile özellikle fiziksel büyüme ve gelişmenin belirgin bir şekilde hızlanması, yaşam şeklinin değişmesi, sigara kullanımı, diyet yapma arzusu ve spor yapma gibi özel nedenler üniversite öğrencilerinin beslenme alışkanlıklarını değiştirebilmektedir (Saygın vd., 2011:44).

\section{YÖNTEM}

Araştırmanın temel amacl; üniversite öğrencilerinin besin tüketim tespit edilmesidir. Gençlerin beslenme alışkanlıkları son zamanlarda beslenme alışkanlıkları ile ilgili üzerinde durulan önemli konulardan bir tanesidir. Gençlerden önemli bir grup olan üniversite öğrencilerinin de beslenme alışkanlıkları sürekli değişebilmekte ve farklı boyutlara ulaşabilmektedir. Özellikle bilgi ve iletişim teknolojileri, küreselleşme ile beraber tüketim kalıplarındaki sınırların ortadan kalkması ve gençlerin yaşadıkları dinamik çevre bundaki en önemli nedenlerden birkaçıdır. Gençlerin teknolojiyi sık bir şekilde kullanması ve etkilenebilecek bir çevrede yaşamaları bunun en önemli nedenidir. Beslenme ile ilgili en önemli konuların başında da besin tüketim alışkanlıkları gelmektedir.

$\mathrm{Bu}$ araştırmada yöntem olarak nicel araştırma yöntemi kullanılmıştır. Nicel araştırmada veri toplama aracı olarak anket tercih edilmiştir. Farklı zamanlarda Sakarya Üniversitesi öğrencilerinden oluşturulan ölçek aracılığı ile veriler toplanmıştır. Bu araştırma için genel evren üniversite öğrencileri, çalışma evreni ise Sakarya Üniversitesinin lisans ve lisansüstü öğrencileridir. Bu nedenle, araştırmanın çalışma evrenini 2015/2016 eğitim ve öğretim yılı güncel aktif lisans ve lisansüstü öğrenci rakamlarına göre 40.685 öğrenci oluşturmaktadır (SAÜ, 2015). $\mathrm{Bu}$ araştırmada, olasılığa dayalı olmayan örnekleme türlerinden kolayda örnekleme yöntemi tercih edilmiştir. Kolayda örnekleme, el altında bulunan ve kolay ulaşılabilen örneklemdir (Berg ve Lune, 2015:70). Kısaca, evren içinde ulaşılabilen katılımcılar veri toplama sürecine dahil edilmekte ve arzu edilen evren örneklem büyüklüğüne ulaşılıncaya kadar bu durum devam eder (Altunışık vd., 2012:142). Sakarya Üniversitesinde lisans ve lisansüstü öğrencisi olmak şartıyla ankete cevap veren herkesin katılımı kabul edilmiştir. Evreni temsil edeceği düşünülerek (Ceylan, 2011:94 ; Altunışık vd., 2012:37; Can, 2014:28; Coşkun vd., 2015:136-137) 1000 anket çoğaltılarak dağıtılmış ve anketlerden 622 geri dönüş sağlanmıştır. Veri toplama süreci tamamlandıktan sonra ön değerlendirme yapılarak eksik ve hatalı anketler araştırmanın dışında 


\section{Merve IŞKIN ve Mehmet SARIIŞIK}

tutulmuş ve analizler 610 anket üzerinden yapılmıştır. Bu nedenle bu çalışmadaki örneklem veri toplanan 610 öğrencidir.

Çalışmada kullanılan ölçeğin genel hatlarını daha önce yapılan (Yılmaz ve Özkan, 2007; Önay, 2010; Sağlık Bakanlığı, 2011; Arslan ve Akça, 2012; Akça vd., 2013) gibi çalışmalar oluşturmuştur. Bunlara ek olarak ilgili literatür taranmış (Farber Cancer Institue; Demirezen ve Coşansu, 2005; Sezek vd., 2008; Şanlıer vd., 2009; Bozhüyük, 2010; Saygın vd., 2011; Yıldırım vd., 2011; Gül, 2011; AB Bakanlığı, 2011; British Heart Foundation, 2012), uzman görüşü alınmış ve eklemeler yapılarak ankete son hali verilmiştir.

Araştırmanın veri toplama sürecinde bazı önemli kısıtlar ile karşılaşılmıştır. Bu kısıtlardan en önemlileri zamansal ve parasal kısıtlardır. Bununla birlikte özellikle son sınıflardaki öğrencilerin anketlere istenilen düzeyde cevap vermemeleri de önemli bir kısıt olarak ifade edilebilir. Üniversitenin bazı birimlerinin de, veri toplanması için resmi yazı talep etmeleri de önemli bir kısıt olarak söylenebilir. Vize haftasında kütüphanede yapılan yüz yüze anketlerde de öğrencilerin önemli bir kısmı ders çalıştıklarını ifade ettikleri için ankete katılım göstermemişleridir. Özellikle yüz yüze alınan anketlerde hata payının az olacağı göz önüne alındığında bu durumunda önemli kısıt teşkil ettiği ifade edilebilir.

\section{BULGULAR}

Bu kısımda araştırmaya ait verilerin analiz sonuçlarına yer verilmektedir. İlk olarak iç tutarlılığ test etmek için güvenilirlik analizi yapılmış ve Cronbach's Alpha katsayısı 0.823 çıkmıştır. Bu değer sosyal bilimlerce kabul gören bir değerdir. Katılımcıların demografik değişkenlerine, yiyecek ve içecek tüketim sıklıklarına ilişkin frekans bilgilerine yer verilmektedir. Değerlendirmeler sıklık değerleri ve yüzdeler üzerinden yapılmaktadır.

Tablo 2'de katılımcıların demografik değişkenlerine ilişkin frekans bilgileri bulunmaktadır. Katılımcıların \%90'ı lisans öğrencilerinden oluşmaktadır. Katılımcıların \% 46'sının 500 TL ve altı, $\% 25$ 'inin ise 700 TL ve üzeri gelire sahip oldukları görülmektedir. Katılımcıların \% 49'unun gelirlerinin önemli bir kısmını ailelerinden sağladıkları, \%39'unun burs ve kredilerden, \%12'sinin ise gelirlerini çalışarak elde ettikleri görülmektedir. Katılımcıların \%36'sının evde, \%43'ünün Devlet/Kamu Yurdunda, \%16'sının özel yurtlarda ve \%4'ünün ise aile veya akraba yanında ikamet ettikleri görülmektedir.

Tablo 3 incelendiğinde ölçekteki ifadelerin aritmetik ortalamasının genellikle 2 ile 4 değerleri arasında değiştiği görülmektedir. Aritmetik ortalamalar incelendiğinde katılımcılar tarafından en sık tüketilen yiyeceğin ekmek $(\bar{X}=3,98)$ olduğu görülmektedir. Bununla beraber en az tüketilen yiyeceğin ise sakatat $(\bar{X}=2,08)$ olduğu göze çarpmaktadır.

"Ekmek" ifadesine katılımcıların \% 73'ü olumlu yanıt vermiştir. Türkiye genellikle olduğu gibi ekmek çok sık tüketilmektedir. Ekmekteki bu yüksek tüketim Önay (2010) tarafından yapılan çalışmada da tespit edilmiştir. "Pişmiş sebze" ifadesine katılımcıların yaklaşık \% 55'i olumlu yanıt vermiştir. Buda katılımcıların pişmiş sebze tüketimine önem verdiğini göstermektedir. "Tavuk eti" ifadesine katılımcıların \%66'sı olumlu yanıt vermiştir. Buda katılımcılar tarafından tavuk etinin sık olarak tüketildiğini göstermektedir. "Çikolata, şeker vb." ifadesine katılımcıların $\% 59^{\prime}$ u olumlu yanıt vermiştir. Genel olarak çikolata, şeker vb. yiyecekler gençler arasında da çok sik tüketilmektedir. 
Tablo 2: Demografik Değişkenlere İlişkin Bulgular

\begin{tabular}{|c|c|c|c|c|c|}
\hline DEĞİŞKENLER & $\mathbf{N}$ & $\%$ & DEĞISSTKENLER & $\mathbf{N}$ & $\%$ \\
\hline \multicolumn{3}{|l|}{ Cinsiyet } & \multicolumn{3}{|l|}{ Sigara Kullanımı } \\
\hline Kadın & 218 & 35,7 & Evet & 202 & 33,1 \\
\hline Erkek & 392 & 64,3 & Hayır & 406 & 66,8 \\
\hline \multicolumn{3}{|l|}{ Yaş } & \multicolumn{3}{|l|}{ Kilo } \\
\hline 20 ve alt1 & 123 & 20,2 & 60 ve alt1 & 178 & 29,2 \\
\hline $20-22$ & 352 & 57,7 & $61-70$ & 193 & 31,6 \\
\hline $23-25$ & 93 & 15,2 & $71-80$ & 142 & 23,3 \\
\hline 25 ve üzeri & 42 & 6,9 & 81 ve üzeri & 97 & 15,9 \\
\hline \multicolumn{3}{|l|}{ Gelir } & \multicolumn{3}{|l|}{ İkamet } \\
\hline 500 TL ve alt1 & 279 & 45,7 & Ev & 216 & 35,4 \\
\hline $501-700 \mathrm{TL}$ & 179 & 29,3 & Devlet Yurdu/Kamu Yurdu & 264 & 43,3 \\
\hline $701-1000 \mathrm{TL}$ & 83 & 13,6 & Özel Yurt & 100 & 16,4 \\
\hline 1001 TL ve üzeri & 67 & 11,0 & Aile ve Akraba Yanı & 28 & 4,6 \\
\hline \multicolumn{3}{|l|}{ Eğitim } & \multicolumn{3}{|l|}{ Gelir Kaynağ1 } \\
\hline Lisans & 553 & 90,7 & Aile & 298 & 48,9 \\
\hline Lisansüstü & 57 & 9,4 & Burs ve Kredi & 235 & 38,5 \\
\hline & & & Çalışıyorum & 76 & 12,5 \\
\hline
\end{tabular}

"Balık eti" ifadesine katılımcıların yaklaşık \%51'i olumsuz yanıt vermiştir. Buda katılımcıların balık etini çok fazla tüketmediğini göstermektedir. "Sakatatlar" ifadesine katılımcıların yaklaşık $\%$ 68'i olumsuz yanıt vermiştir. Sakatatlar katılımcılar tarafından nadiren tüketilmektedir. Sakatat tüketimindeki bu olumsuz yaklaşım Önay (2010) tarafından yapılan çalışmada da benzer sonuçlar vermiştir. "Çerezler" ifadesine katılımcıların yaklaşık \% 62'si nadiren tükettiğini belirtmiştir. Bu yüzdeye göre katılımcların çerez tüketimini çok fazla tercih etmedikleri söylenebilir. "Margarin" ifadesine katılımcıların yaklaşık \% 57'si nadiren yanıtını vermiştir. Gençlerin margarini çok fazla tüketmedikleri desteklenmektedir. "Pekmez" ifadesine katılımcıların yaklaşık \%59'u olumsuz yanıt vermiştir. Buda katılımcılar tarafından pekmezin çok fazla tüketilmediğini göstermektedir.

Tablo 4 incelendiğinde ölçekteki ifadelerin aritmetik ortalamasının 1,80 ile 4,30 değerleri arasında değiştiği görülmektedir. Aritmetik ortalama incelendiğinde katılımcılar tarafından en çok tüketilen içeceğin çay $(\bar{X}=4,29)$ olduğu göze çarpmaktadır. Bununla birlikte katılımcılar tarafından en az tüketilen içeceğin ise mayasız alkollü İçecekler $(\bar{X}=1,84)$ olduğu görülmektedir.

"Çay" ifadesine katılımcıların \% 81'i olumlu yanıt vermiştir. Toplumumuzda sudan sonra en çok tüketilen içeceğin çay olduğu katılımcılar tarafından da açıkça gösterilmiştir. "Ayran" ifadesine katılımcıların \%55'i olumlu yanıt vermiştir. Toplumumuzda genel olarak çok sık tüketilen milli içecek olarak adlandırılan ayranın katılımcılar tarafından da sıkça tüketildiğini bir bakıma teyit edilmiştir. "Kahve" ifadesine katılımcıların yaklaşık \%94'ü olumlu yanıt vermiştir. Buda katılımcıların kahveyi sık olarak tükettiğini göstermektedir. 
Tablo 3: Yiyeceklerin Tüketim Sıklıklarına İlişkin Frekans Analizi

\begin{tabular}{|c|c|c|c|c|c|c|c|c|}
\hline \multirow{2}{*}{\begin{tabular}{|l} 
Iffadeler \\
\end{tabular}} & \multirow[b]{2}{*}{$\overline{\mathbf{X}}$} & \multirow[b]{2}{*}{ S.S. } & \multicolumn{2}{|c|}{ Hiçbir Zaman } & \multicolumn{2}{|c|}{ Nadiren } & \multicolumn{2}{|c|}{ Sik } \\
\hline & & & $\mathbf{F}$ & $\%$ & $\mathbf{F}$ & $\%$ & $\mathbf{F}$ & $\%$ \\
\hline Ekmek & 3,98 & 1,07 & 18 & 3,0 & 149 & 24,5 & 440 & 72,2 \\
\hline Pişmiş Sebze & 3,89 & 1,02 & 81 & 13,3 & 334 & 54,7 & 191 & 31,3 \\
\hline Tavuk Eti & 3,78 & 0,92 & 8 & 1,3 & 194 & 31,8 & 404 & 66,2 \\
\hline Peynir & 3,76 & 1,02 & 18 & 3,0 & 192 & 31,5 & 398 & 65,2 \\
\hline Çikolata, Şeker & 3,68 & 1,04 & 11 & 1,8 & 239 & 39,2 & 358 & 58,7 \\
\hline Yumurta & 3,57 & 1,14 & 30 & 4,9 & 241 & 39,5 & 237 & 55,2 \\
\hline Zeytin & 3,48 & 1,14 & 37 & 6,1 & 236 & 38,7 & 333 & 54,6 \\
\hline Taze Meyve & 3,39 & 0,99 & 18 & 3,0 & 312 & 51,2 & 278 & 45,6 \\
\hline Pilav, Makarna & 3,38 & 1,02 & 12 & 2,0 & 183 & 30,0 & 411 & 67,4 \\
\hline Yoğurt & 3,30 & 1,04 & 18 & 3,0 & 347 & 56,9 & 244 & 40,0 \\
\hline Taze Sebze & 3,29 & 1,11 & 35 & 5,7 & 317 & 52,0 & 255 & 41,8 \\
\hline Kuruyemişler & 3,28 & 1,06 & 28 & 4,6 & 333 & 54,6 & 247 & 40,5 \\
\hline Tost, Pizza & 3,26 & 1,04 & 26 & 4,3 & 333 & 54,6 & 247 & 40,5 \\
\hline Simit & 3,21 & 1,08 & 25 & 4,1 & 363 & 59,5 & 216 & 35,4 \\
\hline Kirmız1 Et & 3,16 & 1,01 & 34 & 5,6 & 362 & 59,3 & 210 & 34,5 \\
\hline Baklagiller & 3,13 & 1,05 & 36 & 5,9 & 342 & 56,1 & 223 & 36,6 \\
\hline Lahmacun, kebap & 3,01 & 1,01 & 25 & 4,1 & 411 & 67,4 & 172 & 28,2 \\
\hline Reçel, Marmelat & 2,99 & 1,04 & 47 & 7,7 & 370 & 60,7 & 190 & 31,1 \\
\hline Hamur Tatlıları & 2,98 & 1,07 & 51 & 8,4 & 373 & 61,1 & 182 & 29,8 \\
\hline Bal & 2,96 & 1,07 & 52 & 8,5 & 376 & 61,6 & 179 & 29,4 \\
\hline Sucuk, Sosis vb. & 2,92 & 1,10 & 56 & 9,2 & 384 & 63,0 & 167 & 27,4 \\
\hline Sütlü Tatlılar & 2,91 & 1,00 & 31 & 5,1 & 429 & 70,3 & 143 & 23,5 \\
\hline Tereyağ1 & 2,87 & 1,11 & 67 & 11,0 & 377 & 61,8 & 163 & 26,7 \\
\hline Balık Eti & 2,63 & 1,06 & 65 & 10,7 & 440 & 72,1 & 101 & 16,5 \\
\hline Çerezler & 2,63 & 1,22 & 24 & 3,9 & 382 & 62,7 & 201 & 33,0 \\
\hline Pekmez & 2,60 & 1,16 & 121 & 19,8 & 361 & 59,1 & 123 & 20,1 \\
\hline Margarin & 2,35 & 1,12 & 163 & 26,7 & 249 & 57,2 & 95 & 15,6 \\
\hline Sakatatlar & 2,08 & 1,19 & 249 & 40,8 & 279 & 45,7 & 72 & 11,8 \\
\hline
\end{tabular}

Tablo 4'e bakıldığında "Bitki çayları" ifadesine katılımcıların \%53'ünün nadiren yanıtını verdiği görülmektedir. Bitki çaylarının gençler arasında çok fazla tercih edilmediği söylenebilir. "Mayalı alkollü içecekler" ifadesine katılımcıların \%86'sı olumsuz yanıt vermiştir. Ayrıca "mayasız alkollü içecekler" ifadesine katılımcıların yaklaşık \%88'i olumsuz yanıt vermiştir. Bu iki veri katılımcıların çok sık alkol tüketmediklerini göstermektedir. İçecek tüketimindeki bu sonuçlara benzer sonuçlar Önay (2010) tarafından yapılan çalışmada da tespit edilmiştir. Özellikle çay tüketimindeki sonuçlar Yılmaz ve Özkan (2007) ile Akça ve arkadaşları (2013) tarafından yapılan çalışmalar ile de desteklenmiştir. Buda Türkiye'de çayın toplum içerisindeki önemini göstermektedir. 
Tablo 4: İçeceklerin Tüketim Sıklıklarına İlişkin Frekans Analizi

\begin{tabular}{|l|c|c|c|c|c|c|c|c|}
\hline \multicolumn{4}{|c|}{} & \multicolumn{2}{c|}{ Hiçbir Zaman } & \multicolumn{2}{c|}{ Nadiren } & \multicolumn{2}{c|}{ S1k } \\
\hline \multicolumn{1}{|c|}{ İfadeler } & $\overline{\mathbf{X}}$ & S.S. & F & $\%$ & F & $\%$ & F & $\%$ \\
\hline Çay & 4,29 & 0,96 & 11 & 1,8 & 100 & 16,4 & 494 & 81,0 \\
\hline Ayran & 3,64 & 0,98 & 12 & 2,0 & 256 & 42,0 & 338 & 55,4 \\
\hline Kahve & 3,48 & 1,98 & 32 & 5,2 & 289 & 47,4 & 284 & 46,6 \\
\hline Hazır Meyve Suyu & 3,33 & 1,08 & 32 & 5,2 & 217 & 52 & 258 & 42,3 \\
\hline Kola, Gazoz vb. & 3,10 & 1,22 & 74 & 12,1 & 294 & 48,2 & 231 & 37,9 \\
\hline Süt & 2,91 & 2,42 & 85 & 13,9 & 365 & 59,8 & 159 & 26,1 \\
\hline Taze Meyve Suyu & 2,67 & 1,04 & 72 & 11,8 & 418 & 68,5 & 114 & 18,7 \\
\hline Bitki Çayları & 2,63 & 1,22 & 130 & 21,3 & 326 & 53,4 & 151 & 24,8 \\
\hline Mayalı Alkoller & 1,92 & 1,26 & 347 & 56,9 & 175 & 28,7 & 82 & 13,5 \\
\hline Mayasız Alkoller & 1,84 & 1,21 & 364 & 59,7 & 174 & 28,5 & 66 & 10,8 \\
\hline
\end{tabular}

\section{SONUÇ VE ÖNERİLER}

Bütün insanların beklenti, istek ve ihtiyaçlarının farklı olduğu ve bu durumun da insanların tüketim alışkanlıklarını değiştirdiği bilinmektedir. Son yıllarda meydana gelen küresel gelişmeler, insanların tüketim kalıplarını değiştiren bu beklenti, istek ve ihtiyaçları daha da derinleştirmektedir. İnsanlar bilgi ve iletişim teknolojileri sayesinde, kendilerinden oldukça uzakta bulunan bir ihtiyacı talep etme güdüsüne sahip olabilmektedirler.

Değişen tüketim kalıplarının kendini en belirgin şekilde hissettirdiği kavramlardan birisi de beslenmedir. Beslenmeyi bu kadar belirgin bir tüketim kalıbı haline getiren de besin kavramıdır. Her geçen gün insanların beslenme kavramına karşı tutumları değişmekte ve tükettikleri besinler değiştirmektedir. Özellikle dinamik çevresel yapı nedeniyle tüketim kalıpları en çok değişen gruplardan biride gençlerdir. Gençler içerisinde önemli bir orana sahip olan üniversite öğrencilerinin de tüketim kalıpları değişmektedir. Özellikle fizyolojik dürtülerin önemli bir kısmını oluşturan beslenme alışkanlıkları da gençler arasında sürekli bir değişim göstermektedir. $\mathrm{Bu}$ anlamda gençlerin beslenme alışkanlıkları ile ilgili yapılan çalışmalar literatürde sıkça tekrarlanmaktadır. Bu çalışmanın sonuçlarının da literatüre bu anlamda katkı sağlayacağı düşünülmektedir.

Gençler içerisinde önemli bir kesimi oluşturan öğrencilerin besinler tüketim davranışları hem yeterli ve dengeli beslenmeleri ve beslenme alışkanlıkları açısından önem taşımaktadır. Bu nedenle öğrencilerin tükettikleri besinlerin sıklık dereceleri önem taşımaktadır. Yiyecekler açısından bakıldığında peynir, tavuk eti, yumurta, pişmiş sebze, ekmek, çikolata-şeker, kuruyemiş, zeytin, simit, pilav-makarna, taze meyve ve tost-pizza gibi yiyecekler en sık tüketilen yiyecekler olarak öne çıkmaktadır. Bunla beraber sakatat, balıketi, sucuk-sosis margarin ve pekmez gibi ürünler en az tüketilen yiyeceklerdir. İçeceklerde ise ayran ve çay en çok tüketilen içecekler iken, alkol grupları ve süt en az tüketilen içeceklerdir. Bütün bunlar öğrencileri sosyokültürel yaşantısı ve ekonomik imkânlar ile açıklanabilir.

Yapılan bu araştırma kapsamında bazı öneriler getirilebilir. Yoğunlukla öğrencilere hizmet sunan işletmeler, besin değeri yüksek, sağlıklı ve kaliteli menüler ile hizmet vermelidir. Öğrenciler düzenli olarak sabah kahvaltısı yapılmalı, kahvaltıda besin değeri yüksek besinler tüketilmelidir. Ayrıca öğlen ve akşam yemeklerinde de saat ve besin dengesinin olduğu bir düzen 
oluşturulmalıdır. Son olarak ise, öğrencilere besinler, besin değerleri, besin öğeleri gibi bazı temel konularda seminer ve konferanslar aracılığı ile bilgiler verilmelidir.

\section{KAYNAKÇA}

Akça, R. P. Arslan, R. ve Demirbaş, E. A. (2013). Farklı Üniversitelerde Eğitim Gören Çocuk Gelişimi Lisans ve Önlisans Öğrencilerinin Beslenme Alışkanlıkları. Akademik Bakış Dergisi, 38:118.

Alaunyte, I. Perry, J. L. and Aubrey, T. (2015). Nutritional Knowledge and Eating Habits of Professional Rugby League Players: Does Knowledge Translate into Practice? Journal of the International Society of Sports Nutrition. DOI 10.1186/s12970-015-0082-y.

Altunışık, R. Coşkun, R. Bayraktaroğlu, S. ve Yıldırım, E. (2012). Sosyal Bilimlerde Araştırma Yöntemleri SPSS Uygulamalı. Sakarya: Sakarya Yayıncılık.

Arslan, R. ve Akça, R. P. (2012). Çocukların Eğitiminde Rol Model Oluşturacak Olan Eğitimci ve Usta Öğretici Adaylarının Beslenme Alışkanlıkları, Dicle Üniversitesi Sosyal Bilimler Enstitüsü Dergisi, 4(2):101-119.

Baban, M. (2010). Obez ve Diyabetik Yetişkinlerin Beslenme Bilgi Düzeyleri, Beslenme Alı̧̧kanlıkları, Diyet ve Diyabetik Ürünleri Algılama Düzeylerinin Karşlattırmalı Olarak Değerlendirilmesi. Yüksek Lisans Tezi, Sağlık Bilimleri Enstitüsü, İstanbul.

Baysal, A. (1990). Beslenme, Kültür Bakanlığı Yayınları, Ankara: Türk Hava Kurumu Basımevi.

Berg, B. L. and Howard L. (2015). Sosyal Bilimlerde Nitel Araştırma Yöntemleri, (H. Aydın, çev.). Konya: Eğitim Yayınevi.

Bozhüyük, A. (2010). Çukurova Üniversitesi Sağlık Bilimleri Öğrencilerinin Sağlıklı Yaşam Biçimleri Davranışlarının Değerlendirilmesi, Yayınlanmamış Uzmanlık Tezi, Çukurova Üniversitesi Sağlık Bilimleri Enstitüsü, Adana.

British Heart Foundation. (2012). How Healthy Is Your Diet? Questionnaire, https://www.bhf.org.uk/, E.T.: 25.11.2014.

Bulduk, S. (2002) Beslenme İlkeleri ve Mönü Planlama, Ankara: Detay Yayıncılık.

Can, A. (2014). SPSS ile Bilimsel Araştırma Sürecinde Nicel Veri Analizi, Ankara: Pegem Akademi Yayınları.

Ceylan, S. (2011). Destinasyon Marka İmajı ve Pamukkale Yöresinde Bir Uygulama, International Journal of Economic and Administrative Studies, 4(7):89-102.

Coşkun, R. Altunışık, R. Bayraktaroğlu, S. ve Yıldırım, E. (2015). Sosyal Bilimlerde Araştırma Yöntemleri SPSS Uygulamalı, Sakarya: Sakarya Yayıncılık.

Demirezen, E. ve Coşansu, G. (2005). Adölesan Çağı Öğrencilerde Beslenme Alışkanlıklarının Değerlendirilmesi. Sürekli Tip Eğitimi Dergisi, 12(8):174-178

Farber Cancer Institute, (2014). Eating Habits Questionnaire, https://www.bhf.org.uk/, E.T.: 25.11.2014.

Gül, T. (2011). Sağ̆lklı Beslenme Kavramı Ve Üniversite Öğrencilerinin Beslenme Alışkanlıklarına Yönelik Tutum ve Davranışlar: Çukurova Üniversitesi Örneği. Yayınlanmamış Yüksek Lisans Tezi, Çukurova Üniversitesi Sosyal Bilimler Enstitüsü, Adana. 
Koniuszy, Z. Goluch, Magda Rygielska and Ilona Nowacka, (2013). Nutritıonal Status and Nutritional Habits of Men With Benign Prostatic Hyperplasia or Prostate Cancer-Prelıminary Investıgation. Scientiarum Polonorum Technol. Aliment. 12(3):319-330.

Köksal, O. (2000). Glda ve Beslenme. Kayseri: Erciyes Üniversitesi Matbaası.

Mazıcıŏglu, M. M. ve Öztürk, A. (2003). Üniversite 3. ve 4. Sınıf Öğrencilerinde Beslenme Alışkanlıkları ve Bunları Etkileyen Faktörler. Erciyes Tıp Dergisi, 25(4):172-178.

Önay, D. (2010). Selçuk Üniversitesi Akşehir Yüksekokulu Hemşirelik Öğrencilerinin Beslenme Alışkanlıkları Ve Besin Tüketimi Sıklıkları. Fırat Sağlık Hizmetleri Dergisi, 5(14):127-146.

Saü (Sakarya Üniversitesi), (2015), http://yazilmaistatistik.sabis.sakarya.edu.tr/tr/ DerseYazilmaIstatislikleri/YeniKayitlar/Index, E.T: 17.12.2015.

Saygın, M. Öngel, K. Çalışkan, S. Yağlı, M. A. Has, M. Gonca, T. ve Kurt, Y. (2011). Süleyman Demirel Üniversitesi Öğrencilerinin Beslenme Alışkanlıkları, Süleyman Demirel Üniversitesi Tıp Fakültesi Dergisi, 18(2):43-47.

Schwenk, G. H. ve Schwenk, M. (2006). Beslenme Atlası, (Alav G. çev.). Ankara: ODTÜ Yayıncılık.

Sezek, F. Kaya E. ve Doğan, S. (2008). Üniversite Öğrencilerinin Genel Beslenme Alışkanlıkları, Katkılı Besinler Hakkındaki Bilgi Görüş ve Tutumları, Çankaya Üniversitesi Fen-Edebiyat Fakültesi Dergisi, 10:117-134.

Sormaz, Ü. ve Şanlıer, N. (2015). Yiyecek-İçecek Hizmetleri Bölümü Çırak Öğrencilerinin Öğün Tüketimi ve Sağlık Sorunlarının Değerlendirilmesi, Kastamonu Ĕ̆itim Dergisi, 23(4):1619-1632.

Şanlıer, N. Konaklığlu, E. ve Güçer, E. (2009). Gençlerin Beslenme Bilgi, Alışkanlık ve Davranışları İle Beden Kütle İndeksleri Arasındaki İlişki, Gazi Ĕ̆itim Fakültesi Dergisi, 29(2):333352.

T.C AB Bakanlığı, (2011). What Are Your Food Habits and What Do You Actually Know About Food? Results Of Questionnaire, Again, Heyday Of Health, Grundtvig Partnership Project, 20111-TR1-GRU06-24163-1.

T.C Sağlık Bakanlığı, (2011). Bakanlığımız İl Sağlık Çalışanlarında Şişmanlık Durumunun Değerlendirilmesi, www.mersinsaglik.gov.tr/ Download\%5C301_4_176_ Rehber.doc, E.T.: 25.11.2014.

Tayar, M. Korkmaz, N. H. ve Özkeleş, H. E (2011). Beslenme İlkeleri. Bursa: Dora Basım Yayın.

Türkan, C. (2005). Turizmde Beslenme İlkeleri ve Mönü Planlama. Ankara: Detay Yayıncılık.

Wetherilt, H. (2006). Sağlıklı Beslenme, Sağglklı Yaşam. İstanbul: İstanbul Ticaret Odası Yayınları, Yayın NO: 2006-32.

Yıldırım, İ. Yıldırım, Y. Tortop Y. ve Poyraz, A. (2011). Afyon Kocatepe Üniversitesi Beden Eğitimi ve Spor Yüksekokulu Öğrencilerinin Beslenme Alışkanlıkları ve Bunları Etkileyen Faktörler, Uluslararası İnsan Bilimleri Dergisi, 8(1):1375-1391.

Yılmaz, E. ve Özkan, S. (2007). Üniversite Öğrencilerinin Beslenme Alışkanlıklarının İncelenmesi. Firat Sağllk Hizmetleri Dergisi, 2(6):87-104. 